\title{
Vinogradniško in kletarsko izrazje v prleški vasi Cven
}

\author{
Mateja Kosi
}

Prispevek prinaša narečni slovar vinogradniške in kletarske terminologije, glasoslovni opis in krajše besedilo panonskega prleškega govora vasi Cven ter primerjavo zbrane leksike z drugimi do zdaj objavljenimi dialektološkimi prispevki iz prleškega narečja in s še neobjavljenim gradivom za slovar medžimurskega narečja. Preverjena je tudi pojavnost v slovarjih. Leksemi so v slovarju opremljeni z označevalniki glede na časovnost oziroma pogostnost in postavljeni $\mathrm{v}$ sobesedilo.

Ključne besede: vinogradniška in kletarska terminologija, panonska narečna skupina, prleško narečje

Wine-growing and wine-cellar terminology in the village of Cven, Prlekija

This article presents a dialect dictionary of wine-growing and wine-cellar terminology as well as a phonetic description and a short text written in the subdialect of the village of Cven, part of the Prlekija dialect of the Pannonian dialect group. The lexical material gathered is compared to other articles on the Prlekija dialect as well as unpublished material for the Međimurje dialect dictionary. Attestation in dictionaries is also examined. Words in the dictionary are labeled for frequency, and are put into context.

Key words: wine-growing terminology, wine-cellar terminology, Pannonian dialect group, Prlekija dialect

\section{Uvod}

0.1 O vinogradniški in kletarski terminologiji v prleškem narečju je bilo objavljenih že nekaj razprav avtorice Mihaele Koletnik, in sicer Vinogradniška terminologija na Gomili pri Kogu (Koletnik 1996), Miklošičevo vinogradniško besedje v Pleteršnikovem slovarju (Koletnik 2004), Izposojenke v prleškem vinogradniškem besedju (Koletnik 2006a), Vinogradniška terminologija na Ženiku in v Biserjanah, rojstnem kraju Antona Korošca (Koletnik 2006b). Vinogradniški terminologiji je na straneh 389-400 posvečeno tudi eno poglavje članka Besedje v severovzhodnem narečnem prostoru (Koletnik 2007). Poleg znanstvenih pri- 
spevkov sta $\mathrm{z}$ istega področja nastali še dve diplomski deli, ${ }^{1} \mathrm{v}$ katerih sta bila raziskana govora vasi Cven in Kapelski Vrh. ${ }^{2}$

0.2 V prispevku so obravnavani narečni vinogradniški in kletarski izrazi, ki jih uporabljajo vinogradniki iz vasi Cven, ki leži 5 kilometrov severovzhodno od Ljutomera na zahodnem robu Panonske nižine - gre za prleški govor panonske narečne skupine.

Cvenu najbližji vinogradi spadajo v vinorodno deželo Podravje, natančneje v ljutomersko-ormoški vinorodni okoliš. Vinogradništvo in vinarstvo sta tu zelo stari in razširjeni kmetijski panogi, zato je z njima povezano izrazje pogosto rabljeno in bogato. Ker pa se načini pridelave in predelave grozdja modernizirajo, se stara orodja, posode in postopki ter z njimi izrazi zanje umikajo iz rabe.

Osnova prispevka je narečno besedilno gradivo, ki sem ga posnela na terenu $\mathrm{s}$ petimi informatorji in ga zapisala $\mathrm{v}$ fonetični transkripciji. ${ }^{3}$ Vprašalnice za posamezni vodeni pogovor sem si predhodno pripravila sama, ${ }^{4}$ informatorjem pa sem pustila tekoče govoriti, da so pozabili na diktafon oz. kamero ${ }^{5}$ in govorili kar najbolj po domače. Izrazje in pomeni so primerjani s tistimi iz objav Mihaele Koletnik $(1996,2004,2006 a, 2006 b, 2007)$ in s še neobjavljenim gradivom za slovar medžimurskega narečja Đura Blažeke.

\section{$1 \quad$ Kratek opis naglasa in glasoslovja}

1.1 Naglas je dinamični in ni vezan na določeno mesto $\mathrm{v}$ besedi. Naglašeni samoglasniki so dolgi ali kratki, nenaglašeni le kratki. Zastopniki psl. staroakutiranih dolgih in novoakutiranih kratkih samoglasnikov ter umično naglašenih $ə, e, o$ so $\mathrm{v}$ govoru večinoma še kratki.

1 Zadnjih deset let se vinogradniška (in kletarska) terminologija predvsem v diplomskih nalogah načrtno zbira po vseh vinorodnih okoliših tudi na Oddelku za slovenistiko Filozofske fakultete v Ljubljani pod mentorstvom red. prof. dr. Vere Smole.

2 Mateja Kosi, Vinogradniško in kletarsko izrazje v prleški vasi Cven (2007) pod mentorstvom red. prof. dr. Vere Smole; Nataša Safran, Vinogradniško besedje na Kapelskem Vrhu (2004) pod mentorstvom doc. dr. Mihaele Koletnik.

3 Moji informatorji so bili: (A) Marija Makoter, rojena leta 1941 na Cvenu, gospodinja; (B) Miroslav Babič, rojen leta 1954 na Ptuju, kmet; (C) Ferdinand Rošker, rojen leta 1947 na Cvenu, tekstilni tehnik; (Č) Branko Kosi, rojen leta 1960 na Cvenu, mesar; (D) Anton Kosi, rojen leta 1947 na Cvenu, diplomirani obramboslovec. Vsem se za sodelovanje najlepše zahvaljujem.

4 Pomagala sem si s strokovno literaturo o vinogradništvu in kletarstvu ter $\mathrm{z}$ navedenimi diplomskimi deli in strokovnimi članki.

5 Kot priloga k diplomskemu delu je nastal tudi dvajsetminutni film. 


\subsection{Samoglasniki}

1.2.1 Sistem dolgih samoglasnikov je monoftongičen. Dolgi naglašeni samoglasni-

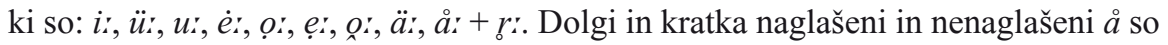
le rahlo zaokroženi. Kvantitetna razlika med naglašenima $r$ in $r$ ni več zaznavna.

Izvor:

$i:$ < stalno dolgi ir ('zi:må, s'vi:jå 'svinja', 'pi:šän 'pišem', k'li:n), v prevzetih besedah (måš́i:n 'naprava, mlin', g'lixxåti 'ravnati');

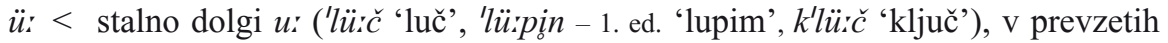
besedah (b'rüıtiff 'pokopališče');

$u_{i}$ < stalno dolgi ll: ('vu:k 'volk', 'dusk 'dolg', 'ču:n 'čoln'), redko staroakutirani t po mlajšem podaljšanju ('du'gå - prid. ž. sp. 'dolga'), o pred $n, m\left(z^{\prime} v u: n\right.$ 'zvon', z'du:mi 'zdoma');

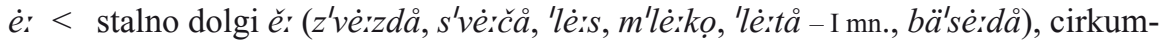
flektirani a ('lè:n 'lan', 'dè:n 'dan', 'mèxx 'meh', dvojnično 'vẹ:s/'vèrs 'vas');

$o:$ < cirkumflektirani $o$ ('no:č, g'no:j, 'nọ:s, 'bo:k, mä'sơ:), zgodaj podaljšani novoakutirani o ('ko:s, 'o:s - oboje R mn.), stalno dolgi q: (k'lo:p, 'so:t, go'lo:p, 'zo:p, 'go:bäc, 'rọ:kå), novoakutirani o v besedah ('dọitå, dvojnično 'vọ:lål'vollå 'volja'), v prevzetih besedah ('šo:šstår 'čevljar');

ẹ: < stalno dolgi ę: ('pẹ:t, i'mẹ:, g'rẹ:då, 'pẹ:tå, 'mẹ:xkå, 'vẹ:žän - 1. ed. 'vežem', p'lẹ:šän - 1. ed. 'plešem'), cirkumflektirani $e$ ('lẹ:t 'led', 'pẹ:č, pä'pẹ:l, vä'čẹ:r, $\left.s_{o}^{\prime} c e e^{\prime}\right)$, redko novoakutirani a ('pẹisji), cirkumflektirani a dvojnično v besedi ('vẹss/'vérs), v prevzetih besedah ('fẹrxtåli so 'prosili so');

$o_{x}:$ < stalno dolgi a: (g'ro:t 'grad', x'ro:st 'hrast', t'ro:vå 'trava', g'lorva ' glava'), cirkumflektirani $a \mathrm{v}$ besedah ('lợ:Š 'laž', 'čorst 'čast'), zgodaj podaljšani a v besedi ('to:l $l$ - R mn. 'tal'), v prevzetih besedah iz a: ('vo:gå 'tehtnica');

$\ddot{a}:$ < novoakutirani a v zadnjem besednem zlogu ('pärs 'pes', 'värs 'ves'), redko v prevzetih besedah iz a: pred $j$ ('xärjzl 'stranišče', b'rärjdä);

$\stackrel{\circ}{a}:^{2} \quad a^{\prime}$ v besedah, prevzetih iz knjižnega jezika (žu'på:n);

$r:<$ stalno dolgi rio ('kr:f, s'mr:t), staroakutirani $r$ ('pr:st, 'sr:na).

1.2.2 Zaradi večinoma nepodaljšanih starih akutov je sistem kratkih naglašenih samoglasnikov bogat, pogostnost njihovega pojavljanja pa visoka. Kratki naglašeni samoglasniki so: $i, \ddot{u}, u, e, o, \ddot{a}, \ddot{a}$.

Izvor:

$i<$ staroakutirani $i$ ('lipå, 'ribå, kọ'bilå; 'miš, 'nič, 'sit), v prevzetih besedah ( $g$ 'lix 'ravno', 'cigäl), redko po mlajšem naglasnem umiku na prednaglasni $i$ (p'rinås);

$\ddot{u}<$ staroakutirani $u$ ('küpå - R ed., k'rüxå - R ed., k'lükå 'kljuka'; k'rüx, 'küp, 'tü), v prevzetih besedah ( $g^{\prime}$ rünt 'grunt, posest', 'fürtọx 'predpasnik');

$u<$ staroakutirani t̆ ('vunå 'volna', 'punå - prid. ž. sp. 'polna'), prednaglasni tı po umiku naglasa s končnega kratkega zloga ('buxå 'bolha'), $u$ pred $j$ ('mujcäk), v skupinah buj-, muj-, nastalih po metatezi iz u'mi(:)-, u'bi(:)- (x'mujvati, 'bujti), redko umično naglašeni $o$ v položaju pred $n, m$ ('kunäc, 'dumå), o pred $j$ iz ńn ('kuj), v prevzetih besedah (kå'ruzå, 'lustär), v prevzetih besedah iz knjižnega jezika ('̌̌upnik); 
$e$ < staroakutirani ě (b'rẹzå, st'rexå, 'lẹto, 'rẹzåti, pọ'vẹdåti; 'dẹt 'ded', 'sẹn 'sem'), ě pred $r$ ('mẹrå, 'vẹrå), v prevzetih besedah ('lẹdär, 'kẹks);

$o<$ staroakutirani $Q$ ('dogå, 'gobå, 'točå), novoakutirani o (š'kodå, 'nošå, 'nosing, p'rosing; š'kof, 'koš, k'rop, st'rok, 'pot), umično naglašeni o ('kozå, 'oså, 'kotäl, 'dobrå), po mlajšem naglasnem umiku naglašeni o ('bogåt, 'potplåt), v prevzetih besedah ('zokli), redko iz $a$ v prevzetih besedah (f'lokšå);

$\ddot{a}<$ staroakutirani e (s'räčå, 'dätälcå 'deteljica'), novoakutirani e ('zäljä, 'žänix ‘ženin', 'mäčän - 1. ed. 'mečem', k'mätå - R ed. 'kmeta', 'sädän 'sedem'; k'mät, 'čäp), umično naglašeni e ('žänå, 'čälo, 'räbro, 'näsän, 'räčän), staroakutirani ě pred $n, m$ (x'rän, 'sämän 'seme', kọ'länọ), e po mlajšem naglasnem umiku ('čätrtäk), novoakutirani a v nezadnjem besednem zlogu ('mäšå 'maša', 'säjä 'sanje', 'väški, f'säxnä 'usahne', prä'mäknä, 'päxnä 'zadeti v oko', 'gänä 'premakniti; čustveno se dotakniti'), v prevzetih besedah pred $j$ (š́päjzå, 'cäjtĐgä);

å < staroakutirani a (k'råvå, 'måti, 'kåmän; b'råt, p'råf, zd'råf), prednaglasni $a$, naglašen po mlajšem naglasnem umiku ('nåpnä jọ) in v prevzetih besedah ('måntl, 'fås̆änk).

1.2.3 Nenaglašeni samoglasniki so samo kratki: $i, u, o, \ddot{a}$, å. Zanje je značilna nizka stopnja redukcije, reducirajo se predvsem ob zvočnikih, ki postanejo zlogotvorni: $r, l, n$. Izglasni $i$ je še nekoliko manj napeto izgovorjen kot nenaglašeni $\underset{g}{i} \mathrm{v}$ internih zlogih. Akanja, ikanja in ukanja govor ne pozna.

$i<i$ (prednaglasni: tišščir, zídorr; ponaglasni: g'råbitio, 'xodinn; izglasni: 'xodi, nå

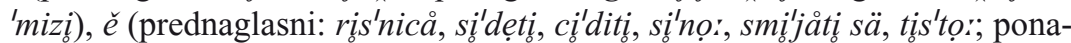

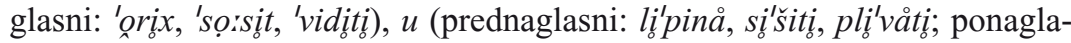
sni: 'påzdịxå; izglasni: b'råtio, 'si:ni);

$u<\mathrm{v}$ prevzetih besedah (tu'rizän, ku'bik); v onomatopejskih besedah ('kuku);

$o<o$ (prednaglasni: ókor; ponaglasni: 'jågoda), $Q$ (prednaglasni: zobjjẹ;; ponaglasni: 'mizo), I (prednaglasni: gọ́čismo; ponaglasni: 'jåbọkå), -o <-at ('dẹlo $j a ̈)$, iz - $-t$ za naglašenima in nenaglašenima $i$ in $\check{e}\left(\right.$ '̌rr:ijo, $x^{\prime} m r$ r:ijo, 'nosijo jä, 'bijo jä, 'tr:pijo jä), -ət ('näso jä), v prevzetih besedah ('fürtox);

$\ddot{a}<$ > (s'täbär, 'čäbär, 'kunäc 'konec'), e (prednaglasni: zällè:ni, vä'sẹ:lå, bälsé:då; ponaglasni: 'näsämọ; izglasni: 'po:lä 'polje', 'mo:rrjä, 'näsä), e (prednaglasni: klälčir, päs'ni:cä 'pesti'; ponaglasni: 'påmät, 'jorsträp; izglasni: 'tälä, 'zänä I mn., 'mizä - I mn.);

å < $a$ (interni zlogi: 'žågåti, 'dẹlåtio; izglasni: 'jågọdå, g'lo:vå, g'rü:škå, k'råvå), v prevzetih besedah $\left(f^{\circ} l o: t\right)$;

$r<$ nenaglašeni $r$ (smr'dẹti, $\left.m r^{\prime} l i: c ̌ c\right)$, po umiku naglasa na prednaglasni zlog ('čätrtäk), po onemitvi samoglasnika ob $r$ (žrg'bẹ: 'žrebe', 'lẹdrnio 'usnjen'), v prevzetih besedah ('nidr'šuxi 'nizki ženski čevlji');

$n<$ po onemitvi samoglasnika ob $n$ ('jåbọšncå, 'suinčncå, s'låmọ'rẹzncå), v prevzetih besedah ('totn'ko:mrå 'mrliška vežica', 'cäjtøgä, 'türrno);

$l<\mathrm{v}$ prevzetih besedah ('måntl). 
1.3 Soglasniški sistem se od sistema slovenskega knjižnega jezika zelo malo razlikuje, saj so soglasniki nastali iz ustreznih soglasnikov v izhodiščnem splošnoslovenskem sistemu (Logar 1981), poleg tega pa:

$v<w$ pred samoglasniki, zvočniki in zvenečimi nezvočniki ('vi:no, 'vodå, v'rå:k), kot proteza pred zadnjimi samoglasniki (v'o:pno, 'vürzdå, 'vüstå, 'vü:š);

$-n<-m$ ('čẹ:n 'hočem', li'dè:n - daj. mn. 'ljudem', 'tå:n 'tam'), redko ń v izglasju ('ogän), v prevzetih besedah ('måntl);

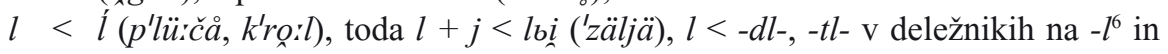
iz primarne skupine $t l, d l$ ('jèrlå 'jedla', c'värlå 'cvetela' - 'šilo), v prevzetih besedah ('lẹdär);

$r<\dot{r}\left({ }^{\prime} r \ddot{x} x a ̊\right), r$ v prevzetih besedah (kråm'pérr); $r$ v skupini -črě- in -žrě-, ki sta ohranjeni (čr'rèrväl 'škorenj’, č́réršsjå, žr 'bẹ: 'žrebe');

$j<n$ in $n ъ j$ ('kuj, 'sükjå, 'lürkjå, 'jivå 'njiva', korä'jẹ: 'korenine', b'låjå 'deska'), $j$ $<\emptyset$ kot zapolnitev zeva ('bijo jä, 'nosijo jä), kot prehodni $j$ med $u$ in zobnimi/ zadlesničnimi soglasniki ('mujcäk, 'gujdäk 'prašič'), v skupinah buj-, muj-, nastalih po metatezi iz u'mi(:)-, u'bi(:)-( (x'mujvati, 'bujti);

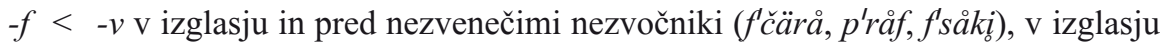
tudi v skupini -ru ('čr $\left.r f, o^{\prime} b r f^{\prime} f\right), p$ - v položaju pred $t\left(f^{\prime} t i c ̌ c\right)$, v prevzetih besedah ('fẹxxtåli so, 'fürtọ 'predpasnik'), -f- < -pf- < -bf-('korf'låšå 'pletenka');

$\check{s} \check{c}<\check{s} \check{t}($ 'küščår, 'iščän, nå 'täščä);

$z d-<v z d-\left(z^{\prime}\right.$ dox'våjä 'poroka', z'dignoti 'dvigniti');

$k<k j$ - v besedi 'kje' ('ke);

$g<k j$ - v sestavljenkah ('nẹi 'nekje', 'nigi 'nikjer');

$x<k, g$ pred $k$ ('mẹ:xki 'mehak', 'läxki 'lahek'), xm- < vm- (x'mujvåti, xm'rètti).

Nezveneči nezvočniki so nastali tudi iz zvenečih v izglasju in po asimilaciji na sledeče nezvočnike, zveneči nezvočniki pa iz nezvenečih prav tako po asimilaciji na sledeče nezvočnike. Vsi nezvočniki se pojavljajo tudi v prevzetih besedah.

\section{Slovar}

Po narečnih pripovedih informatorjev, večkratnih pogovorih z njimi ter na podlagi obsežnega zbranega zvočnega, slikovnega in video gradiva je v mojem diplomskem delu nastal slovarček, v katerem je zbranih okrog 450 iztočnic (od tega jih je $\mathrm{v}$ tem prispevku zaradi omejitve obsega predstavljenih 115). V geselskem članku je najprej navedena glasovno poknjižena iztočnica. Sledi ji ustreznica v narečni transkripciji. Pri samostalniških besedah sledijo oblike za imenovalnik in rodilnik ednine ter oznaka slovničnega spola. Pri glagolskih oblikah navajam nedoločniško obliko in obliko za 1. osebo ednine sedanjika (ponekod 3. oseba, če se oblika za 1. osebo ne uporablja) ter podatek o glagolskem vidu. Pri pridevniški besedi so navedene oblike za vse tri spole ter natančnejša besednovrstna oznaka. Z besednovrstno oznako so označeni tudi prislovi, vezniki in zaimki.

${ }^{6}$ O ł v izglasju deležnikov gl. pri izvoru /ọ/. 
Sledi opredelitev besede z označevalnikom, ki izraz označuje glede na časovnost oziroma pogostnost (redko, zastar. ${ }^{7}$, star. $^{8}$ ), $\mathrm{v}$ tem izboru iz celotnega slovarčka ni terminološko in zvrstno zaznamovanih leksemov. Besede brez označevalnika so nezaznamovane.

Pri vseh besednih vrstah sledi sopomenka iz knjižnega jezika ter pomenska razlaga iztočnice. Sledi ponazarjalno gradivo - sobesedilo, v katerem se narečna beseda pojavlja. Pri nekaterih pomenskih razlagah je navedena tudi sopomenka. Pojavnost leksemov, ki jih ni ne v SSKJ 1-5 in ne v Pleteršnikovem (2006) slovarju (oz. v nobenem od teh slovarjev niso predstavljeni $\mathrm{v}$ enakem pomenu), sem preverila še v nekaterih drugih slovarjih (etimoloških - Bezlaj 1-5, Snoj 1997, Skok 1-4; kajkavskih - Finka 1984-, Lipljin 2002, Blažeka 2010; prekmurskem - Novak 2006; porabskem - Mukič 2005). Če beseda v določenem slovarju obstaja, je to zabeleženo v oklepaju pod geselskim člankom.

\section{Krajšave}

dov. - dovršni glagol; $\mathrm{m}$ - samostalnik moškega spola; mn. - množina; s - samostalnik srednjega spola; nedov. - nedovršni glagol; NŠ - neštevno; prid. - pridevnik; prisl. - prislov; star. - starinsko; strok. - strokovno; zast. - zastarelo; ž - samostalnik ženskega spola

\section{Znaki in simboli}

- $\quad$ za poknjiženo iztočnico uvaja narečni zapis

1 uvaja prvi pomen, če sta vsaj dva

2 uvaja drugi pomen, če sta vsaj dva

$|x x x| \quad$ zamejevalni del razlage

- uvaja frazem

$\rightarrow \quad$ glej, primerjaj

- uvaja razdelek $\mathrm{z}$ večbesednimi strokovnimi izrazi

[..] označuje izpuščeni del besedila

(А), (В) ... označuje informatorja

$\mathrm{xxx}^{*} \quad$ ni v SSKJ

$\mathrm{xxx}^{* *} \quad$ ni ne $\mathrm{v}$ SSKJ ne v Pleteršnikovem slovarju

$\mathrm{xxx}^{-} \quad$ je $\mathrm{v}$ SSKJ, vendar $\mathrm{v}$ drugem pomenu

$\mathrm{xxx}^{--} \quad$ je $\mathrm{v}$ SSKJ in $\mathrm{v}$ Pleteršnikovem slovarju, vendar $\mathrm{v}$ drugem pomenu

$\mathrm{xxx}^{*-} \quad$ ni v SSKJ, je $\mathrm{v}$ Pleteršnikovem slovarju, vendar v drugem pomenu

$\mathrm{xxx}^{-*} \quad$ je v SSKJ, vendar v drugem pomenu, ni v Pleteršnikovem slovarju

$\mathrm{xxx}^{\sim} \quad$ podobno $\mathrm{v}$ SSKJ

$\mathrm{xxx}^{* \sim} \quad$ podobno $\mathrm{v}$ Pleteršnikovem slovarju

Informatorji so označeni s temile črkami: (A) Marija Makoter, (B) Mirko Babič, (C) Ferdinand Rošker, (Č) Branko Kosi, (D) Anton Kosi, z (M) pa je označen govor mene same.

7 zastar. - zastarelo: označuje besede, ki jih poznajo le posamezniki. Ti izrazi so zelo stari, saj se jih že vsaj štirideset let ne uporablja več (tretač, rebljač, cuhta ...).

8 star. - starinsko: označuje besede, ki se umikajo iz vsakdanje rabe. Tovrstni leksemi so ljudem znani, razumejo jih, uporabljajo pa ne več (četrtnjak, kobila, konj ...). 
beteg • 'bätäk bä'tägå m bolezen |vinske trte|: (A) Ọd vrä'mė:nå. Tọ zäj, čè jä 'tåkšọ 'nẹs'tå:lnọ v'rè:mä, 'po्र: 'däš 'po: 'tistå spå'ri:nå, 'nẹkä på 'tüdị ọd bọ'lẹ:znị. G'do jä 'bätäk v gọ'ricåx, 'nä?

bobika • 'bubikå -ä ž, star. grozdna jagoda: (Č) 'Nẹgdå, g'do: jä b'rox:två 'bi:lå, 'tẹ: sọ 'totä s'to:rä 'båbä t'ri 'bubikä 'gor nå ... 'nä, nåtäk'nolä [..]

brač - b'ro:č -a m trgač |obiralec grozdja|: (M) 'Kåk pa 'räčätä 'totion lì'dè:n, ki p'ri: däjọ b'ro:t? (A) B'ro:čị.

brajda • b'rä:jdå -ä ž brajda |po ogrodju iz letev napeljana vinska trta|: (C) 'Kåbrniok bị 'moglå na spọm'lo:t. 'Tistọ: 'vi:dịš, g'däj ... 'tọ: 'läxkọ 'dumå na b'rärjdåx 'tüdi 'vi:dišs, 'nä.

brati • b'råtị 'bä:rän nedov. trgati |grozdje|: (A) 'Zå på, f pọn'dė:läk på 'bä:rämo, sọ nån 'räkli zå ši'ponå, kå 'morämọ 'žẹ pällåtị.

bratva b'rox:två -ä ž trgatev: (Č) 'Nẹdå, g'do: jä b'rox:två 'bi:lå, 'tẹ: sọ 'tợä s'tơ:rä 'båbä t'ri 'bubikä 'go:r nå ... 'nä, nåtäk'nolä [..]

cuhta*9 - 'cü:xtå -ä ž, zastar. blago, ki je varovalo zmleto grozdje, da je ostalo $v$ košu stiskalnice: (Č) 'Nẹ:, 'tẹ: på mi jä 'Rusọf S'tånkọ på 'u:n 'tọ: råz'lågọ, kå sọ 'nẹgdå 'mẹlị 'tåkšnä p'räšä, kå sị 'nẹkåk, 'tåk kåk 'änọ 'kurpọ 'mẹjọ. 'Kurpọ, på 'nợtri blå'gọ:, 'tåk kåk ọd 'änägå 'žåklå. In f 'tistị 'žåkäl sị d'jọ: 'totọ säm'lẹtọ g'rọ:zdjä, st'rẹtånọ, ọ'kọ:li på 'tẹ: 'kurpọ, 'tẹ: på jä 'tistọ 'nẹkåk stịs'kox:vålọ. Čè sän jås p'råf

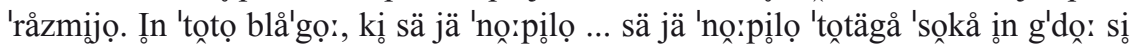
'kåkšägå pi'jọ:ncå 'vidijọ, si 'räkọ, 'tợti på jä 'pijån kåk 'cü:xtå. • pijan kak cuhta popolnoma pijan: 'pijån kåk 'cü:xtå

čep • 'čäp -å m 1 čep |lesen zamašek|: (Č) 'Tọ:, 'čäp. Plutọ'vinåstio. 'Tọ: 'tü: 'notrị p'ri:dä, 'zä:j 'notrị 'täčä. $\rightarrow$ ŠTopelu 2 čep po obrezovanju preostali del rozge, navadno z dvema očesomal: (A) 'Toti 'čäp jä 'näjč 'nè: g'no:.

četrtnjak $\longrightarrow$ štr'jo:k -å m, star. sod, ki drži 150 litrov: (D) Štr'jo:k jä 'tẹ: s'tọ: 'pẹdäsẹt. davati* - 'do:våti 'do:vlä (3. os.) nedov. dajati |sok iz tropin pri stiskanju|: (Č) 'Kåk 'dugọ 'do:vlä, 'tåk 'dugọ s'ti:snäš 'vün. Dọ t'rik'rox:t 'nẹgị.

doga • 'dogå -ä ž doga |deska za sestavljanje lesenega soda|: (Č) Nå pọlọv'jo:kị jä 'dogå. 'Notri. • žalostna doga 'žålọstnå 'dogå lesena deska, s katero se nagne sod, da tekočina do konca izteče: (Č) 'Žålọstnå d'rèivå, 'žålọstnå 'dogå, d'rü:gọ på 'nè:. $\rightarrow$ DREVA

dreva • d'rè:vå -ä ž • žalostna dreva 'žålọstnå d'rè:vå lesena deska, s katero se nagne sod, da tekočina do konca izteče: (Č) 'Žålọstnä d'rè:vä. 'Mislịn, kå sän jọ cèlọ s'kü:rijọ, kå jä sprx'nè:lå. $\rightarrow$ DOGA

držati • drožåti dr’ži: (3. os.) nedov. 1 držati |imeti prostornino za določeno količino tekočine|: (Č) 'Tọ: 'nẹgi 'cirkå dr'ži: 'pẹ:t 'litrọf 'vändå. 2 ohranjati uporabnost: (A) 'Tüdi škrọ'pi:vọ nä dr'ži: 'dužä. 3 držati |ohranjati kaj v določenem položaju| • držati kak pes ježa ironično trdno držati: (Č) 'No, 'vidiš, 'zäj på sä 'tọ: 'tåk zå'tẹ:gnä in 'tọ: drr'ži: kåk 'päs 'jė:žå. 'Zå på šä 'tọ: ọd'rè:žäš, på šä 'pơ: pọ'nücåš 'dålä, nä.

9 V članku Mihaele Koletnik Vinogradniška terminologija na Ženiku in v Biserjanah ... (Koletnik 2006b: 246) je cuhta razložena kot leseni obroči, sestavljeni v obliki koša, kar je po mojem gradivu koš v prvem pomenu (gl. iztočnico koš). 
dverca • d'vẹ:rcå d'vẹ:rc s mn. vratca |zapiralo odprtine na sodu, namenjene za čiščenje|: (A) 'Näj 'nọvä når'rẹ:dị. 'Tọ: 'tẹ 'morä f'sä s'küp 'nọ:vọ - d'vẹ:rcå på f'sä s'küp 'nọ:vọ nårẹ:tị. $\rightarrow$ TIRELJ, TUREN

dveri • d'väri -ị s mn. pokrov koša pri stiskalnici za grozdje: (C) 'Jå, kär ịz 'näj'vẹ:čjägå v 'näj'månšägå nållå:gå, nå 'vrı:x på sä 'dänäjọ d'värị. $\rightarrow$ POD

ferunika** fä'runikå -ä ž, zastar. daljši reznik: (A) 'Jå, 'un jä 'tü:, 'tån 'pọ:läk 'nåšix, på f 'Sẹvrọvịx gọ́ricåx på jä 'un 'mẹjo sp'lox ... 'un jä 'mẹjo 'nè: d'vo: 'kujå, 'un jä 'mẹjọ nå'mẹstọ 'kujọf pọ š'tirị fä'runikä.

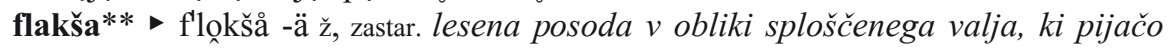
ohranja hladno: (Č) 'Tọ: jä f'lokšåa, lia'sè:nä iazdälå:vä, 'jås sän 'zä:j 'sicär 'dọ: ọbrọ̣:čä 'dẹlåtio igz 'rọstf'räjå, kå 'tẹ: 'tọ: 'påč nä rjå'vė:jä, 'tọ: sọ 'mẹli 'såmọ zå 'tọ:, kå jä 'dužä píjjåčå 'bi:lå 'notrị x'lådnå.

gantar • 'gåntår -å m lega |lesena podloga za sode v kleti|: (M) 'Tottị 'dè:1? (Č) 'Gåntårị. glava - g'lo:vå -ä ž vrhnji del trsa, iz katerega raste rodni les: (A) D'rügọ nä pis'ti:š ... nå 'kuji f'sä pịs'ti:š, på 'tẹ 'totị d'vo: 'räzni:kå, kä s'tåi, z g'lo: vä på g'rẹ: f'sä 'do:l.

graba' g'råbå -ä ž spodnji, najnižji del vinograda: (B) 'Tọ: pọ'mè:nio, kå 'zä:j g'do: 'uni 'čist 'dọ:l p'ri:däjọ, sọ ... v g'råbị.

grabica • g'råbịcå -ä ž 1 odvodni jarek med deli vinograda: (B) Nå f'såkšša 'pẹdäsẹt 'mẹtrọf jä 'bijọ, 'kåk bị̊ 'tọ: 'räkọ, 'vẹrtịkålni̊, 'nejjä, 'vẹrtịkålå jä v g'råbọ, 'tọ: sä p'ro:vị, 'vodọ'råvnọ, 'vodọ'råvni ọd'vod 'vodä in 'tọ: sä jä 'räklọ g'råbịcå. $2 \mathrm{del}$ vinograda med dvema odvodnima jarkoma: (C) V d'rü:gi ål på f t'rẹ:tji g'råbịcị. Pọ 'pr:vị g'råbịcią, f 'pro:vän 'totän, 'prọ:vị prä'xọ:t, d'rü:gị prä'xọ:t på 'kunäc gọ'ric. Gộricä sọ 'tüdì bị'lẹ̣: pọ g'råbịcåx nå'räjänä, 'tẹ: på pọt 'provoọj g'råbịcọj på pọt d'rü:gọj g'råbịcọj sọ 'zäj, 'nä.

grot - g'rot -å m grot |lijaku podobna priprava pri grozdnem mlinu, v katero se strese grozdje|: (Č) 'Tü: 'go:r p'ri:dä g'rot, 'tọ:, nå 'tọ:. Än 'tåkši, , 'mọ:n gå 'doläx, f pìv'nici gå 'mọ:n. $\rightarrow$ ŽRELO

gutedel** 'gut'ẹ:dl -dlå m žlahtnina |trta z navadno petdelnimi listi, srednje velikimi grozdi in jagodami rdeče ali rumeno zelene barve|: (C) Žlåxt'ninå, pọ 'nåšän 'gut'ẹ:dl. 'Tọ: jä jä'dilnå 'sortå. 'Tọ: sä nä p'rẹ:: šå. 'Tọ: 'ni 'vi:nọ.

gviht** g'vixt -å m utež |za povečevanje sile vzvoda na stiskalnico|: (Č) 'Tọ: sọ g'vixti, 'pr:vọ 'vẹ:kị, 'vẹ:kị jä prä'målọ, 'tẹ: på sä šä 'moräjọ 'må:li s s'coj ọ'bẹsịtị, kå 'tẹ: jä 'tọ: 'vẹ:kšṣ ä'fẹkt, kå 'bolä s'ti:snä [..]

igla • 'iglå -ä ž kovinska koničasta os vretena: (C) 'Tẹ: på 'tọ: f'sä s'küpär z'lè:zị nå'zäj 'notrị, kär 'tü: ọt s'podäj jä på 'iglå, kị us'mẹrjå, kå sä 'tọtio 'kåmän nä 'ni:xå 'sẹ:n på 'tô:.

izabela • izå'bẹlå -äž izabela |samorodna trta z zelo velikimi listi in srednje velikimi rdeče vijoličastimi grozdi|: (C) İzå'bẹlå på 'ju:rkå, 'såmọ 'tistọ 'bol 'målọ, 'näj'vä:č på sä jä š'må:rnịcå, 'såmọ 'tọ: jä 'zä:j žẹe 'nẹkäj, prät s'tọ: 'lè:tị.

jurka** — ju:rkå -ä ž samorodna trta z zelo velikimi listi in velikimi modro vijoličastimi grozdi: (C) İzå'bẹlå på 'jurrkå, 'såmọ 'tistọ 'bol 'målọ, 'näj'vä:č på sä jä š'må:rnicåa, 'såmọ 'tọ: jä 'zä:j žẹ 'nẹkäj, prät s'tọ: 'lè:tị. 
kabrnik • 'kåbrniok -å m, strok. kabrnik|grozdni nastavek pred cvetenjem|: (c) 'Kåk 'vün pọ'žänä is s'to:rägå 'lè:så 'målọ k'rox:tkị zä'lè:ni 'listäk, g'rox:tåjọ g'rozdäki 'tåkši 'må:lị, ki måš ọp'čutäk, kå jä g'rozdäk, 'tọ: 'šä jä 'kåbrnion.

kad • 'kåt -di ž kad |velika, zgoraj širša, odprta lesena ali plastična posoda|: (C) 'Tẹ: på 'tü: s'täčä 'vün, nås'to: vịn 'go:r 'tơtọ 'cè:f, 'tẹ: på 'dänän 'dox:1, 'tẹ: på 'dänän 'kåt 'tü:, 'nä, ìs 'kådi på 'tẹ: 'potlii 'pumpåmọ f 'sọ:dä.

kajla • 'käjlå -ä ž zagozda iz lesa za zagozdenje sodov: (Č) 'Čố:käj, 'tọ: på sọ 'käjlä.

kamen • 'kåmän -mnå m utež na spodnjem delu vretena: (C) [..] 'tẹ: på gå s'pü:ščåš, 'tå:n dvị'güvläš 'go:r z vrä'tänọm, s 'kåmnọn på vrä'tänọn, 'tå:n z'dignäš 'gớ:r, 'tẹ: på 'tọ: p'ri:dä 'vo्र:gå.

klin • k'li:n -å m tečaj |za zapiranje koša pri stiskalnici na zadnji strani|: (Č) 'Tån på sọ 'rigli nå 'ovi st'rọ:nio, k'li:ni. Nå 'ovị st'rọ:ni sọ k'li:ni, på 'lü:kjä, kå s'küp, 'nä, f'täknäš, 'tü: på sọ k'lü:čí, kå s'küp 'zåpräš. $\rightarrow$ RIGELJ

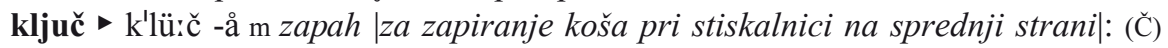
K'lü:č. Zå zå'pirråjä 'totägå, kå gå 'zåpräš s'küpär, 'koš. Kå 'koš s'küp 'zåpräš. 'Tån på sọ 'riglị nå 'ovi st'rọ:nị, k'li:nị. Nå 'ovi st'rọ:nị sọ k'li:nị, på 'lü:kjä, kå s'küp, 'nä, f'täknäš, 'tü: på sọ k'lü:čí, kå s'küp 'zåpräš.

kobila ${ }^{--}$kọ'bilå -ä ž, star. deblo vinske trte: (A) 'Tọ:, 'därä på sä, 'tọ:, på sä 'tẹ: 'räčä kọ'bilå. Čè sä, 'mislion, ọt 'därä smọ ọb'no:vlåli, 'tẹ: smọ 'tü: zọb'rẹzåli, 'tẹ: på jä 'tri:s ... sä 'räčä kọ'bilå, 'tọ: på sọ 'tẹ 'kujio. (D) 'Jå, 'tọ: sọ kọ'bilä, 'jå. Kọ'bilä sä 'vün 'mäčäjọ, 'nä, g'do sä 'sè:kå.

koleno - kọ'länọ -å s kolence |odebeljeni del trsa, iz katerega poganjajo listi|: (C) Zå'rådi 'tägå, kär jä 'tọ: 'tåk nås'tơ:vlänọ. Kär 'tü:, f t'rẹ:tjän, čä'tritän kọ'läni sä pọ'jåvị 'kåbrnik [..]

konj - 'kuj -å m, star. pri obrezovanju preostali del rozge s petimi ali šestimi očesi: (A) 'Kä jä špå'rọ:n, jä 'kuj, 'jå. 'Tọ: jä 'kuj ... Dọ ọt 'tü:, nä, ọt 'tü: 'jä 'kuj [..] $\rightarrow$ šPARON

korbflaša** • 'korfl'låšå -ä ž pletenka: (D) Pọ 'vi:nọ på sän 'šo्र: s 'korf'låšọj, f'kẹrọ mi jä 'virt nållèijọ 'vi:nọ î̀ 'püčlå.

koš • 'koš -å m 1. koš |obod pri stiskalnici za grozdje|: (C) 'Tẹ: på 'zä:j, v'zämäš, 'tå:n 'dänäš, k'däj jä 'kớš nå'lợzäni, kär 'tẹ: 'tämọ sä 'tẹ: 'potlli 'räčä 'kớs. 2. visoka, spodaj zožena pletena posoda za prenašanje |gnoja na hrbtu|: (Č) 'Kơ̌š zå g'nọ:j nọ'sitio. P'lätäni̊. 'Tọ: sä nå 'råmọ 'lẹpọ 'vro:žä, 'tẹ: på g'rẹ:š. På tị 'notrị nålmäčä; 'tọ: jä 'tẹ:kọ 'višä, kå tị 'nämrä zå kộ'lè:r lä'tẹtio, ion 'tọ: 'läxkọ 'näsäš. 'Totị jä 'målọ 'må:lio, 'bọjšs jä 'målọ 'vẹ:kšì, kå 'tẹ: 'vä:č 'näsäš. 3. velika količina, množina |rozg in listja na trsu|: (A) Č̉ 'tọ: 'zäj 'nä bị 'rẹzåli, 'tọ: bi 'zäj nå spọm'lơ⿱:t 'cè:lì 'koš 'bijọ.

krajnik • k'räjnik -å m prvi trs v vrsti: (M) 'Kåk sä 'räčä 'totämọ 'pr:vämọ 'tr:sion? (A) K'räjnik. K'räj, då jä pro k'ro:ji. 'Tọ: jä k'räjnịk.

lagvenica** ' 'lågväncå -ä ž večji lijak za točenje vina v sod: (Č) 'Lågväncọ šä 'mợ:n. (A) 'Låkväncå. 'Tọ: 'därä prä'tơ:čäš, 'nä, 'zäj 'tåk s 'pumpọj, 'därä på smọ 'pẹškị, på 'tü nå pọlọv'jox:k 'dänäš, kär t'råxtår jä prä'må:lì. 'Tü 'änọ 'kuntọ v'lè:jäš, 'tẹ på pọ'målän 'täčä. Lè'sė:nä smọ 'nẹgdå 'mẹlị. $\rightarrow$ LAKOVNICA 
lakovnica* - 'låkväncå -ä ž večji lijak za točenje vina v sod: (A) 'Låkväncå. 'Tọ: 'därä prä'tơ:čăš, 'nä, 'zäj 'tåk s 'pumpọj, 'därä på smọ 'pẹškia, på 'tü nå pọlọv'jo:k 'dänäš, kär t'råxtår jä prä'mållị. 'Tü 'änọ 'kuntọ v'lè:jäšs, 'tẹ på pọ'målän 'täčä. Lè'sè:nä smọ 'nẹgdå 'mẹlį. $\rightarrow$ LAGvenICA (Bezlaj 2: 122: lakomica; Novak 2006: 215: lakovnica)

latica • 'låticå -ä ž lesena deščica za ogrodje koša pri stiskalnici: (D) [..] präp'rẹčçilå, kå bị g'rọ:zdjä 'vün šp'ricålọ, 'tåk kåk måš 'zäj f xịd'råvliačniox p'räšăx p'låstiočnọ m'rẹžọ. På 'tẹ: 'låtịcä.

legnar • 'lẹgnär -å m betonski podstavek lege: (Č) 'Lẹgnär. 'Lẹgnär jä nå bị'tọ:nị.

macljek • 'måcläk -å m kladivce pri klopotcu: (B) 'Tợtå 'dèll sọ 'vẹtroncä, g'rẹ:däl jä, nå g'rẹ: dli sọ 'måcläki̊, 'tẹ: på jä 'däskå på 'mätlå.

manga* 'mọ:jngå -ä ž, redko vzvod: (C) På 'mäknäš 'totọ vä'rịgọ, 'tå kå 'tẹ: g'rơ:tå vz'vọ:t, 'nä, 'mọ:jngå, kåk sä 'räčä pọ 'pr:läškị. (Bezlaj 2: 194: monga)

metla • 'mätlå -ä ž šibnata metla na klopotcu, ki vetrnice usmerja v smeri vetra: (B) 'Totị 'dè:1 sọ 'vẹtrnncä, g'rẹ:däl jä, nå g'rẹ: dlị sọ 'måcläkị,, 'tẹ: på jä 'däskå på 'mätlå.

mlin • m'li:n -å m grozdni mlin |mlin za mletje, drozganje grozdja|: (A) V m'li:n. (M) Zå 'kå på g'rẹ: v m'lii:n g'rost? (A) Kå zd'robị 'jågọdä. $\rightarrow$ TRETAČ

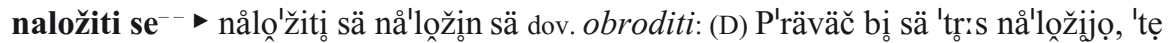
på bị sä ... (A) s'xirrọ.

naštekati** • nåš'tẹkåtị -ån dov., redko postaviti |kolje|: (C) 'Tẹ: på 'potlli nåš'tẹkåš 'koljä 'såmọ, 'kolä 'näjp'rẹ:t nåš'tẹkåšs, kå jịx nå'pikåš, kå nå'rẹ: dịš 'vṛ̂stọ, 'tå:n, kẻ bọdọ 'potli pọ'såjäni 'tra: sị.

obdeluvati** ọbdä'lüvatị -vlän nedov. obdelovati |kmetijske površine|: (D) Zå'volọ obdällå:vä. Kär sä 'zäj f'sä st'rojnọ ọbdällüvlä, 'nä.

obroč • ọbrọ:č -å m obroč a |ozka ploščata lesena priprava v obliki kroga, ki omogoča oblikovanje koša pri starejših stiskalnicah|: (D) 'Tọ: jä b'rẹzọvå 'tåkšåa 'vè:jå, nå 'pọ:l v'rèzzånå. 'Tẹ: på jä i̊s 'tägå nå'rẹ:tị 'rink, ọb'rọ:č. 'Tẹ: på jä ... s'podị 'dänä 'näj'vẹ:kšägå, 'tẹ: på 'sig'dợrr 'mè:šägå, 'tå kå s'tox̌ăc 'dẹlå 'u:n. b |ozka ploščata priprava v obliki kroga, ki povezuje lesene dele soda, flokšel: (Č) 'Tọ: jä f'lokšå, lị'sė:nä iozdä'lå:vä, 'jås sän 'zä:j 'sicär 'do: ọb'rọ:čä 'dẹlåtị i iz 'rosttf'räjå, kå 'tẹ: 'tọ: 'påč nä rjå'vè:jä [.. $]$

oka • 'ọ:kå -ä ž mn. 'ọ:kä oko |zametek brsta na oleseneli rozgi v zimskem času|: (A) [..] 'tọ: på sọ räz'ni:kị. 'Totị, 'nä? 'Tọ: jä 'tơtị 'du:gi, kị må dä'sẹ:t, 'ọ:k [..]

olup* ọ'lüp -ỉ ž lupina |lupina grozdne jagode|: (M) Ọk'rọ:k på 'måmọ ... (A) lu'pinå. (M) Lu'pinọ åli ọ̣'lüp? (A) Ọ'lüp, ọ'lüp jä 'tọ:, 'jå. Tọ: jä ộlüp, 'jå.

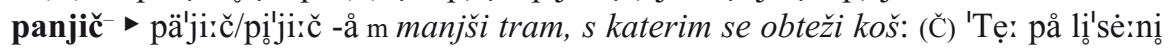
'koš, nä, lì'sè:ni 'koš, 'tẹ: je 'potli 'notri f f'koš p'ri:dä trọ'pinä, zm'lẹtọ g'rọ:zdjä, 'pot 'go:rr nå 'tọ:, på pi'jiičị. Pij'jicčị på p'ri:däjọ dọ 'provaägå p'rẹ:špäjå. (D) Pä'jiičị. (Č) Päjiičci, no, pä'jičči, 'jå, 'jås på sän 'räkọ pìjiičçi.

panoga- - 'pånọgå -ä ž, star. zalistnik |zalistni poganjek|: (A) 'Tọ: sọ 'pånọgä, 'tọ: z'rơ:sä 'cè:lå 'rozgå. 'Jå, 'pånọgä so 'tọ:. 'Pånọgå jä 'tọ: pọ 'nåšä. Zå'listniok jä 'pånọgå. 'Tọ: jä 'rơzgå, 'tọ: på sọ 'zäj 'pånọgä, zållistniok, 'tọ: jä 'list. (Bezlaj 3: 8: panoga) 
petljičje* pät'li:čjä -å s, NŠ, zastar. pecljevina: (C) 'Jå, pät'li:čjä jä 'tọ:. Kär 'tå:n, 'tọ: sä 'tẹ:, kå g'do: jä råz'dẹvläš, 'nä, 'totọ pät'li:čjä sä 'vr:žä fk'räj. 'Tọ: jä ọt'på:t.

pintar* ' 'pintår -å m, star. sodar |izdelovalec sodov|: (Č) 'Såmọ jä x'rox:st 'po्x: žẹe 'tåk, 'tọ: på žẹ 'pintåri z'no:jọ, kė gå t'rẹbå pọd'rè:tio.

pintovec** ' 'pintọväc -fcå m iva |vrba, katere veje se uporabljajo za vezanje šparonov|: (D) 'Nåš F'rånčäk jä 'nẹgdå f'sä s 'pintọfcọn 'vẹ:zọ.

pipa • 'pipå -ä ž pipa |priprava za točenje vina iz soda|: (M) 'Kå på 'tọ:? (Č) 'Pipå.

$\operatorname{pod}^{-}$'pot -då m 1 dno |spodnji, osnovni del stiskalnice iz lesenih desk|: (C) 'Zåčnämå s 'podå. 'Tọ: jä 'pot, nå 'kẹrägå sä nållågå g'rọ:zdjä. 2 pokrov iz lesenih desk, s kate-

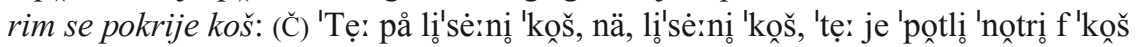
p'ri:dä trọ'pinä, zm'lẹtọ g'rọ:zdjä, 'pott 'gơ:r nå 'tọ:, på píjijičịi. $\rightarrow$ DVERI

poden $^{*} \bullet$ 'pọ:dän -dnå $m \bullet$ prednji poden p'rè:dji 'pọ:dän prednja, čelna stran soda zadnji poden 'zo:dji 'pọ:dän zadnja stran soda: (̌C) 'Tọ: på sọ 'pọ:dni, nä. P'rè:dji på 'zo:djị. På 'tọ: jä 'pọ:čänọ, 'vidioš, 'tọ:. Ålị nä 'pü:ščå zå'äjnkråt, ålị jä 'pọ:čäni̊ xì'di:č.

polovnjak • pọlọv'jôx:k -å m sod, ki drži 300 litrov: (A) 'Näjp'rẹ:t sä pịv'nicå s'pucå, på pọlọv'jox:k v'mujä, på p'räšå sä 'morä v'mujti, på pộ'sọdvå, kä sọ 'pütä på 'kọntä, på 'tọ:, käj 'nücåš. • ovalni polovnjak sod ovalne oblike: (A) Ọ'vålni pọlọv'jox:kị. polž • 'pu:š -ža m polž |vijačno zavit del mlina, ki potiska grozdje v mletje|: (C) 'Jå, čè på šä 'dänäš 'rẹblåčå k'coj, 'tẹ: på, 'tẹ: på råspäc'lujä. Kär šä 'tọ: jä, 'tẹ: 'dänäš 'änọ 'sitọ s'coj, ki nä piśsti:, kå bị, ål på nå 'pu:š jä, 'tåkšnä kị, 'säj tọ: sä nå 'tơtän, ti 'läxkọ, nå kọ'vi:nskän ti 'läxkọ pọ'kơ:žän, 'käj pọ'mẹ:nì 'rẹblåč, kị jä 'bijọ nå 'istị nå'či:n nåp'rơ:vläni prị s'to:rän.

poščip > pọščìp -å m, star. šipon: (A) Pọščci:p, 'tọ: på jä, 'jojj, 'vidioš, 'zå på 'väč slọ'vä:nski nä 'vè:n ... ší'pon.

potirati - pọti'råti pộtirån dov., za trs pognati |narediti poganjke|: (A) 'Un dä 'zäj nå spọm'lox:t, drr'gọ:č dä pọ'tirọ, 'tåk kåk dọ 'zäj, g'rọ:zdjå 'punọ 'gorä 'mẹjọ, 'såmọ f'sä 'doj s'ko:plä.

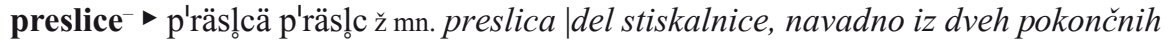
tramov, med katera se namesti vzvod|: (C) 'Tẹ: på sọ p'räslocä, 'zo: djä på p'rẹ:djä p'räsı̊cä. • prednje preslice p'rẹ:djä p'räslocä |preslica, ki je pri stiskalnici bližja vretenu| zadnje preslice 'zo:djä p'räslocä |preslica, ki je pri stiskalnici dlje od vretena|: (C) 'Totä stọ'jẹ:čä, stọ̣jẹ:čị trå'movị sọ p'räslacä, kị sọ nå 'zo: djị p'räslocio sọ vä'rigä 'notrị nå'dẹvånä.

preša • p'räšå -ä ž 1 stiskalnica |za grozdje|: (C) Zå'tọ: kå 'ti jix 'dẹvläš 'zäj, kọ nållo:gåš p'räšọ, 'nä [..] 2 prostor, v katerem se stiska grozdje: (C) [..] 'tẹ på sä jä žẹ 'vidlọ, kå šä jä 'kumäj 'såmọ 'målọ, 'tistọ, 'kä sä jä pọ 'vrixi pọ́ päniolọ ịn jä, 'tẹ: på jä zå'di:šålå 'cè:lå, 'cè:lå p'räšå pọ 'tistän.

prešanje • p'rẹ:šåjä -å s sortirano grozdje, pripravljeno za stiskanje: (C) [..] 'mislịn, kå dä 'rẹnskị 'färtịk 'tå:n 'nẹgị dọ änịx 'änịx, kå bọmọ žẹ zå'čẹ:lị p'rẹ: šåti 'rẹnskägå, 'tẹ på, 'ovọ på, 'kä bọmọ b'rålì, bọmọ b'råli šä kå f 'ki:štåx ọs'tọ:nä, på 'tẹ: 'tistọ v gọ'ricåx ọs'tọ:nä, 'potlị si p'rọ:tio 'go:rr 'vozzimọ, 'nẹkäj på f 'kådi 'dẹvlämọ. Kå nä 'mẹ:šåmọ f'küpär p'rẹ:šåjå. 'Tå kå 'mi 'tẹ: 'potlị vä'čẹ:r p'rẹ:šåmọ šä d'rü:gọ 'rundọ, 'tå kå jä 'tẹ: d'rü:gị 'dè:n k'rẹ:di šä 'tẹ: zå 'tistọ, 'kä dä sä v nä'dẹlọ 'pọ:brålọ. 
prešar • p'rẹ:šår -å m kdor dela pri stiskalnici za grozdje, tudi za druge: (A) 'Nåšå 'måmå sọ 'tọ: sp'lox 'dẹlålị. Cị́lọ 'tå:k zå p'rẹ:šårä.

prešati • p'rẹ:šăti -ån nedov. stiskati |npr. grozdje|: (C) 'Tọ: jä jä'dilnå 'sortå. 'Tọ: sä nä p'rẹ:šåa. 'Tọ: 'ni 'vi:nọ.

prešpanj** p'rẹ:špäj/p'rẹ:špåj -å m sleme |močen tram kot vzvod na vrhu stiskalnicel • prvi prešpanj 'pr:vị p'rẹ:špäj sleme, ki pri stiskalnici z dvema slemenoma pritiska na koš drugi prešpanj d'rü:gi p'rẹ:špäj sleme, ki pri stiskalnici z dvema slemenoma pritiska na prvega: (Č) In 'tọ: på jä 'pr:vị p'rẹ:špäj, ki p'ri:dä nå pịjjicčä, 'totị d'rü:gị på 'totämọ pọ'mo: gå, 'tü:, 'zäj trä'nutnọ. 'Tọ: jä 'tåk 'dobrọ 'nẹxčä prärâ'čünọ, kå 'tọ: 'lẹpọ 'dẹlå. Čè bi 'tơtị d'rü:gị p'rẹ:špäj 'bolä 'tü: 'bijọ, bị mọ'gọ:čä pọ'čilọ ål på käj 'tåkšägå. • (C) 'Tẹ: på spis'ti:š 'totä vä'rigä 'mäknäš 'vün, på spiss'ti:š 'go:rr nå 'koš p'rẹ:šsåj, sä 'tämọ 'räčä, 'tọ: på jä p'rẹ:špåj [..]

prijeti- pri'jẹ:tị p'ri:mä (3. os.) dov. sprejeti določeno količino grozdja: (C) 'Vẹ:ki g'rot, kå g'rẹ: 'notrị 'vändå 'cè:lå, 'cè:lå, änọ d'vè:, änọ d'vė: 'tọtị 'pütị p'ri:mä s'rè: dji.

prstek - 'pr:stäk -å m, star. vitica: (A) 'Jå, 'tọ: sä 'potli så'mọ: 'vẹ:žěr, 'viš 'tọ:, z 'vitịcooj. 'Tọ: sä 'räčä 'pr:stäkị.

pučel* 'püčäl -člå m sod |navadno manjšil|: (Č) 'Püčäl. Zå 'mänä jä f'sä 'püčäl.

puta • 'pütå -ä ž brenta: (A) 'Näjp'rẹ:t sä piov'nicå s'pucå, på pọlọv'jo:k v'mujä, på p'räšå sä 'morä v'mujtio, på pọ'sọdvå, kä sọ 'pütä på 'kọntä, på 'tọ:, käj 'nücåšs.

putar \'pü:tår -å m brentač: (D) 'Dokiçc šä 'so: lidd'jẹ: zå 'pütä nọ'sitị, dọ 'pü:tåriọ. rebljačc* \'rẹblåč -å m, zastar. pecljalnik |mlin za grozdje, ki obenem razpecljuje|: (C) 'Rẹblåč. 'Tọ: på jä bijọ 'tistị, kị jä råspäc'lo:vọ. Nå'vo:dän m'li:n ål på m'li:n 'rẹblåč, 'nä, 'tọ: stå bị'lo: d'vọ: råz'ličnå.

redčina • 'rẹtčinå -ä ž pas med dvema vrstama vinske trte v vinogradu: (A) 'Tris dọ 'tro:så jä 'rẹtčịnå. 'Tå kå 'tọ: måmä d'vợ: 'rẹ: då, v'mẹs på jä ... 'rẹtčinnå.

remenec* rä'mè:näc -ncå m, nekoč trak iz blaga, s katerim so vezali šparone: (D) 'No, 'änio sọ 'tẹ: žẹ s 'tistịmị rä'mè:ncị, s 'cotåmia 'vẹ:zålị.

rigelj • 'rigäl -glå m tečaj |za zapiranje koša pri stiskalnici na zadnji strani|: (Č) 'Tọ: på jä 'rigäl, nä, 'totị žällẹznì. 'Rigäl. $\rightarrow$ KLIN

ročka • 'roččkå -ä ž ročka |vrču podobna steklena ali lončena posoda|: (A) Čè på sọ prị 'xiži 'kåkšnị ọ'biskị, på 'vi:nọ nå 'mizọ prị́näsämọ v 'roččkị.

roka • 'rọ:kå -ä ž kovinski drog pri stiskalnici, ki povezuje ročico vzvoda pri stiskalnici in sleme: (Č) 'Tọ: sọ g'vixtị, 'pr:vọ 'vẹ:ki, 'vẹ:kị jä prä'målọ, 'tẹ: på sä šä

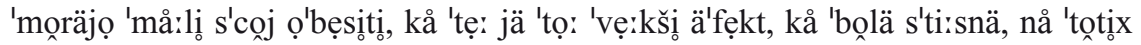
g'vixtịx jä 'rukịcå, 'rukịcå, 'tọ: 'gộ på jä 'rọ:kå nå p'rẹ:špån.

rukica - 'rukịcå -ä ž ročica vzvoda pri stiskalnici, na katero obesimo uteži: (Č) 'Tọ:

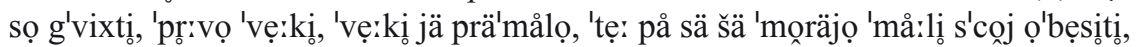
kå 'tẹ: jä 'tọ: 'vẹ:kši ä'fẹkt, kå 'bolä s'ti:snä, nå 'tộxiox g'vixtịx jä 'rukịcå, 'rukịcå, 'tọ: 'gor på jä 'rọ:kå nå p'rẹ:špån.

sep • 'säp -å m zgornji del na pobočju zasajenega vinograda do prvega odvodnega jarka: (B) 'Säp jä 'dè:l gọ'ric, 'gọ:rjọ 'dè:l gọ'ric dọ 'totä 'pr:vä g'råbịcä. $\rightarrow$ SEPINA sepina** sä'pi:nå -ä ž, redko zgornji del vertikalno zasajenega vinograda do prvega odvodnega jarka: (B) 'Tẹ: på jä 'bijọ 'säp, 'gọ:rjị 'dè:l, sä'pinnå, på 'doläx åli på s'pọ:dji 'dè:l. $\rightarrow$ sEP 
sesti • 'sè:sti 'sẹ:dä (3.os.) dov. sesti |končati fazo vage ( $\rightarrow$ VAGA) pri stiskanju|: (C) [..] 'tẹ:kọ 'moräjọ 'iti, kå si 'vơ⿱:gọ, på kå si 'sẹ:dä [..]

sredina • srr'di:nå -ä ž srednji del terasastega vinograda: (B) Sọ v g'råbị, 'jå, åli på sọ nå srr'di:ni åli på nå 'säpí.

stolec $^{-}$s'toläc -å m del klopotca, ki nosi gredelj: (B) 'Jå, 'no, s'toläc, 'tọ: jä 'tợti 'dè:1, ki jä g'rẹ:däl 'goräx, 'nä.

stretani** > st'rẹtåni -å -ọ prid., star. za grozdje zmlet: (Č) Iñ f 'tistio 'žåkäl si 'djo: 'tợtọ säm'lẹtọ g'rọ:zdjä, st'rẹtånọ, ọ'kọ:li på 'tẹ: 'kurpọ, 'tẹ: på jä 'tistọ 'nẹkåk stịs'ko:vålọ.

šafla** 'šo: flå -ä ž lopata: (A) På s 'šo: flåmi 'vün mä'tåli. (Lipljin 2002: 1001: šafla) šef - 'šè:f -å m natega |priprava v obliki cevi za izvlečenje, pretakanje tekočine|: (Č) 'Ovọ på jä nå'vo:dän 'šè:f. Nå'vo:dän 'šè:f zå pi'jåčọ 'vün 'jè:måti. 'Višs, 'tü: sä 'lü:kjå nå'rẹ: dị 'må:lå, på 'tü:, 'nä, ọd'rè:žäš, 'tẹ: på tåk 'nợtri f 'püčäl pọ'ri:näš på pọ'tẹ:gnäš. 'Tẹ: på 'pr:st 'go:rr 'dänäš. $\rightarrow$ ŠLAH

šlah** ড̌llåx -å m natega |priprava v obliki cevi za izvlečenje, pretakanje tekoči$n e \mid:$ (D) 'Vi:nọ îs p'räšä 'täčä pọ š'låxi f 'kåt, 'tẹ på gå ìs 'kådi 'pumpåmọ f 'püčlä. $\rightarrow$ ŠEF

špricati • šp'ricåti -ån nedov. brizgati, uhajati |nekdaj mošt iz pletenega koša zaradi prenaglega stiskanja|: (D) 'Läxkọ 'råzminn, kå jä 'tợtå 'cü:xtå 'bilå 'cotå, kị jä präp'rẹcçilå, kå bi g'rọ:zdjä 'vün šp'ricålọ, 'tåk kåk måš 'zä:j f xịd'råvličnịx p'räšåx p'låstičnọ m'rẹ̌zọ.

štibla- ${ }^{-} \breve{s}^{\prime} t i$ blå -ä ž, star. ročaj $\mid$ za ročni pogon grozdnega mlina|: (B) Š'ti:blå, 'tọ: jä, 'tọ: jä rộčå:j pọt 'čro:kọ L, gi jä 'mẹjọ rọ̣čå:j, kị jä 'bijọ vrt'li:f.

štopelj** š'topl -plå m zamašek $\mid$ na sodu|: (A) 'Jå, jä g'lix 'ovị 'dė:n Å'lẹnkå šllå:, kå jä 'moglå 'kü:pitiọ. Pọ š'toplä. $\rightarrow$ ČEP (Lipljin 2002: 1043: štopl)

tirelj** • 'tirl -rlå m vratca |zapiralo odprtine na sodu, namenjene za čiščenje soda|: (D) 'Tirli bi 'jås 'räkọ. $\rightarrow$ TUREN, DVERCA

tolkač • 'tu:kåč -å m tolkač |približno meter dolgo, batu ali kiju podobno orodje, s katerim se s tolčenjem mečka, drobi jabolka|: (C) 'Tå kå jä 'zä:j, kär 'tü: på bi 'totämu 'tẹ: 'tu:kåč 'mogọ 'räčti, zå'tọ: kå sọ 'nẹgdå, 'nẹgdå sọ 'pẹški t'rẹtåli, zå'tọ: jä 'dọ:bijọ bä'sẹ:dọ, kå sọ xọ'dili, på 'mü:čkålị 'jågọdä, 'jåbọkä på 'nẹsọ 'moglị z'mü:čkåtio, på sọ 'mẹli 'tu:kåčä på sọ 'tu:klị.

tolklja 'tu:klå -ä ž, redko [SSKJ: tukla] jabolčnik: (C) Zå'tọ: sä jä 'tüdị 'räklọ 'nẹgdå 'jåbọšncị 'tu:klå, 'nė: 'jåbọšncå, 'nä, sọ ji 'tu:klå p'råvịliọ, zå'tọ: kå sọ 'moglị 'näjp'rẹ:t s 'tistimio 'tu:kåči pọ'tučtio, kå sä jä, 'totä, 'jåbọkä kå si z'mü:čkọ, kå sọ sä 'potlị 'lẹpšä sp'rẹ:šålä.

trahtar** $\triangleright$ t'råxtår -å m lijak: (M) Å'xå, 'tü 'vi:dịn 'nẹkäj. 'Såmọ i̊'mẹ:nå mi̊ 'räčtä. (A) T'råxtår. (Bezlaj 4: 210: trahtar; Lipljin 2002: 1077: trahter)

tretač** • t'rẹtåč -å m zastar. grozdni mlin: (C) 'Tọ: jä m'li:n, kị, ... 'tọ: jä g'lix m'li:n zå, t'rẹtåč z, 'nọ:, 'tẹ: på bi 'tåk 'räklå 'čist, 'zä:j sị mä s'pọ:tịlå nå 'tọ:, t'rẹtåč z 'rẹblåčọn ål på b'räs. $\rightarrow$ MLIN

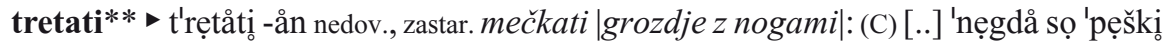
t'rẹtåli, zå'tọ: jä 'dọ:bijọ bä'sẹ:dọ, kå sọ xọ'dilị, på 'mü:čkåli 'jågọdä, [..]

turen- $^{-}$'tü:rn -å m vratca |zapiralo odprtine na sodu, namenjene za čiščenje soda|:

(C) F'sä s'küp, 'cé:li älä'mänt jä 'tü:rno. $\rightarrow$ TIRELJ, DVERCA 
vaga- $^{-10}$ 'vo:gå -ä ž položaj stiskalnice, ko sta sleme in kamen v funkciji bremena: (C) [..] 'tẹ: på gå s'pü:ščåš, 'tå:n dvì'güvläš 'go:rr z vrä'tänọm, s 'kåmnọn på vrä'tänọn, 'tå:n z'dignäš 'gợr, 'tẹ: på 'tọ: p'ri:dä 'vộ:gå.

valek • vållẹ: $\mathrm{k}$-å m priprava v obliki valja, sestavni del mlina za grozdje, ki stiska jagode: (B) 'Tọ: sọ vållẹ:kị, 'såmọ p'låstičncị. 'Tọ: jä bị'lọ: pọt 'kọ:tọn, kå jä 'såmọ k'coj š'lọ:, žreẹlọ, 'nä, 'tẹ: på sä 'påč 'tọ: vṛ'ti: f'küp 'tåk.

veriga - vä'rigå -ä ž kos lesa, ki se vstavlja v preslico: (Č) Vä'rigå, vä'rigå sä zålloži nåd 'gọ:rji⿺ p'rẹ:šspån, kå 'po 'dålä stịs'ko:vlä, kär čè p'ri:dä 'totị g'vixtị 'do:l, dọ 'podå, 'tẹ: 'väč nä stiss'ko:vlä in jä t'rẹbå 'itio d'rü:gọ vä'rigo 'dåtio. • iti po verigo 'ijti pọ vä'rigọ s kosom lesa, ki se vstavlja v preslico, dodatno obremeniti koš pri stiskanju grozdja ( $\rightarrow$ verigA): (M) Kä stä p'rẹ:t 'räklì, kå g'rẹ:tä? (Č) Pọ vä'rigọ.

verižiti - vä'rižiti -in nedov. vstavljati kose lesa v preslico ( $\rightarrow$ VERIGA): (M) Å'jåa, 'tọ: jä zå̀tọ:, kå sä ... (C) vä'riži, 'jå. In 'tẹ: 'tọ: prä'mäknäš, 'ovọ nås'luniš nå 'košs, på vä'rigä prä'mäknäš 'nåt, 'tå:n på gå dvị'güvläš 'go:r. På 'mäknäš 'totọ vä'rigọ, 'tå kå 'tẹ: g'rơ:tå vz'vọ:t, 'nä, 'mọ:jngå, kåk sä 'räčä pọ 'pr:läškị. 'Tẹ: på, 'zä:j, 'tå:n nä pis'ti: 'go:r, kär jä zåvä'rižänọ 'gorị, 'tån på 'kåmän v'lẹčä f'sä s'küp, s'ti:skå.

vetrnica - 'vẹtroncå -ä ž krilo |pogonski del klopotca|: (B) 'Totị 'dè:l sọ 'vẹtrncä, g'rẹ: däl jä, nå g'rẹ: dlị sọ 'måcläkị,, 'tẹ: på jä 'däskå på 'mätlå.

vkapljati** f'ko:plåtio -ån nedov., star. odstranjevati trti vršičke, da bolje rodi: (D) 'No, 'no, 'no, pr 'tikvåx smọ 'räkli, kå sä f'ko:plåjọ. S'to:rị liad'jẹ: sọ 'räkli, kå f'ko:plåjọ. (B) 'Jå, 'bro:ščås 'tåk, 'jå. Pịn'cè:råjä jä 'nọ:vå bä'sė:då. (Lipljin 2002: 164: fkaplati)

vrati • vrå'ti: -'iz ž mn. travnat svet na koncu njive, vinograda: (C) 'Pọd gọ́ricåmị. Nå vråttẹ:x pọd gọ'ricåmi, 'nä, 'tå kå 'tistọ på sọ 'čist zälä'nicå, vrå'ti: 'mi 'räčämọ, kå 'sợ. vreteno • vrä'tänọ -å s vreteno |v obliki vijaka obdelan lesen drog, s katerim se dviguje ali spušča sleme|: (C) 'Nä, 'tọ: jä 'tüdi̊ z 'nämščinä, bi 'räkọ, 'tẹ: på gå s'pü:ščåš, 'tå:n dvị'güvläš 'go:rr z vrä'tänọm, s 'kåmnọn på vrä'tänọn, 'tå:n z'dignäš 'go्र:r, 'tẹ: på 'tọ: p'ri:dä 'vo्र:gå.

vretenariti* vrätä'nårịti -ịn nedov. [P vreteniti] ročno vrteti vreteno: (C) 'Tẹ: på šä 'po:, k'däj jä s'tiš̌jänọ, šä 'äjnkråt rås'kopläjọ, på dro'gọ:č s'küp z'ložỉjọ. 'Tẹ: på vrätä'no:rijọ 'tẹ:: 'potli.

zaveriženi** zåvärižäni -å -ọ prid. zaustavljen s kosom lesa, ki se vstavlja v preslico ( $\rightarrow$ verIGA): (C) 'Tẹ: på, 'zä:j, 'tå:n nä pis'ti: 'gợr, kär jä zåvärrižänọ 'gorị, 'tån på 'kåmän v'lẹçä f'sä s'küp, s'tisskå.

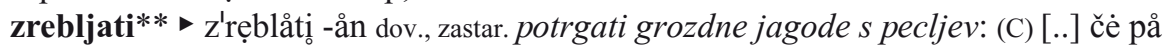
sị š'tẹjọ, kå jä rås'päclånọ bị'loọ:, 'tẹ: på sị gå z'rẹblọ pọ 'prọläškọ. $\rightarrow$ REBLJAČ

zreguljeni** zrä'guljäni -å -ọ prid. zrigolan |zrahljan z zelo globokim prekopavanjem, oranjem|: (C) Kär g'lẹj, 'tọ: jä 'zäj bị'lọ:, 'näjp'rẹ:t jä 'tọ:, 'näjp'rẹ:t jä 'čist 'tåk zrä'guljänọ 'såmọ bị'lọ:, kå 'nẹgå 'ni:č 'goräx, 'nä, 'tọ: jä zrä'guljänọ, zrä'gulänọ jä, kå jä 'zämlå prä'kopånå på pro'rọ:vlänå, zrä'golånå bị 'tọ: 'räkọ, 'zäj zrä'guljänọ pọ 'nåšän, 'pr:läškän, jä zrä'guljänọ.

zreguliti** zrä'guliti -in dov. zrigolati |zrahljati zemljo z zelo globokim prekopavanjem, oranjem|: (D) 'Kåk stä prp'rợ:vlåli. 'Käj jä 'näjp'rẹ:t? (A) 'Näjp'rẹ:t smọ zrä'guliliạ.

${ }^{10} \mathrm{~V}$ članku Mihaele Koletnik Vinogradniška terminologija na Ženiku in v Biserjanah ... (Koletnik 2006b: 251) je vaga razložena kot sopomenka leksema kamen, moje gradivo pa kaže na drugačen pomen (prim. iztočnico kamen). 


\section{Zapis besedila}

Predstavljenih je nekaj leksično bogatih odlomkov zapisanega besedila. Narečnemu zapisu sledi še prestavitev v knjižni jezik, pri čemer sem ohranjala skladenjske značilnosti govorjenega jezika, zato sem prevajala bolj na ravni leksike.

\section{Preša}

C: 'Tọ: jä p'räšå, k'låsičnnå, 'vidišs, 'tisọč 'osänstọ 'šẹdäsẹtägå 'lẹtå jä 'bi:lå nåp'rox:vlänå f'küpär ịn ọt 'tẹ: jä 'šä f'sä, 'tåk kåk jä bị'lọ:, 'råzän ọb'rọ:čä smọ 'nọ:vä nå'rẹ:dlị. To je preša, klasična, vidiš, 1860. leta je bila narejena in od takrat je še vse tako, kot je bilo, le obroče smo nove naredili.

M: Č̀ tä mị 'zäj 'målọ råzlọ'žili, s 'čäså f'sä 'totå p'räšå sp'lox 'jä? Mi boste zdaj malo razložili, iz česa vse ta preša sploh je?

C: 'Jå, 'tơtå p'räšå på jä îs ... Ja, ta preša pa je iz ...

C: 'Zåčnämå s 'podå. 'Tọ: jä 'pot, nå 'kẹrägå sä nållå:gå g'rọ:zdjä. G'rọ:zdjä sä z'lå:gå v ọb'rọ:čä, 'tåk då nås'tå:nä s'toxžäc.

Začneva s poda. To je pod, na katerega se nalaga grozdje. Grozdje se zlaga v obroče, tako da nastane stožec.

M: Å'jå, 'tọ: jä, zå 'tọ: sọ 'tộtio ọb'rọ:čì. Aja, to je, za to so ti obroči.

C: 'Jå, kär ỉz 'näj'vẹ:čjägå v 'näj'månšägå nå'lå:gå, nå 'vr̊xx på sä 'dänäjọ d'värị. Pọk'rọ:f, pọkrióvålọ. 'Tẹ: på sọ p'räslocä, 'zo: djä på p'rẹ:djä p'räslocä. 'Totä stọ'jẹ:čä, stọ'jẹ:či trå'movi sọ p'räslcä, ki sọ nå 'zo: dji p'räslcici sọ vä'rigä 'notrị nådẹånä. 'Tẹ: på 'zäj, v'zämäš, 'tå:n 'dänäš, k'däj jä 'kợs nå'loxžäni, kär 'tẹ: 'tämọ sä 'tẹ: 'pottli 'räčä 'kŏs.

Ja, ker iz največjega v najmanjšega nalaga, na vrh pa se dajo dveri. Pokrov, pokrivalo. Potem pa so preslice, zadnje pa prednje preslice. Te stoječe, stoječi tramovi so preslice, kjer so na zadnji preslici so verige noter nadevane. Potem pa zdaj, vzamě̌, tam daš, ko je koš naložen, ker potem se, temu se potem reče koš.

\section{Deli trsa}

A: 'Kä g'rẹ: s s'tox:rägå 'trơs så 'vün, 'tọ: sọ 'tẹ: räz'ni:kị. Nå'vọ:dnọ 'delåmọ d'vơ: 'kujå på d'vo: räz'ni:kå.

Kar gre iz starega trsa ven, to so rezniki. Navadno delamo dva konja pa dva reznika.

M: Åxå, 'tå kå g'rẹ: ... 'kuji på 'tẹ: g'rẹ:jọ f'såkị v 'änọ st'rọ:n? Aha, tako da gre ... konji pa potem gredo vsak v eno stran?

A: F'såkši v 'änọ st'rọ:n, 'jå. 'Virš, 'tọ: jä 'än 'kuj på 'tọ: jä 'än 'kuj. 'Tọ:, 'kå på jä 'tü: 'vün, 'tọ: på stå d'vo: räz'ni:kå. 'Ädän jä 'tü:, 'ädän på 'tọ:, 'nä.

Vsak v eno stran, ja. Vidiš, to je en konj pa to je en konj. To, kar pa je tu ven, to pa sta dva reznika. Eden je tu, eden pa to, ne.

M: 'Dobro.

Dobro. 
A: 'Tọ:, 'därä på sä, äää, 'tọ:, på sä 'tẹ: 'räčä kộ'bilå. Čè sä, 'mislịn, ọt 'därä smọ ọb'no: vlåli, 'tẹ: smọ 'tü: zọb'rẹzåli, 'tẹ: på jä 'trọs ... sä 'räčä kọ'bilå, 'tọ: på sọ 'tẹ: 'kuji.

To, ko pa se, даว, to pa se potem reče kobila. Če se, mislim, od - ko smo obnavljali, takrat smo tu (z)obrezali, potem pa je trs ... se reče kobila, to pa so potem konji.

D: 'Jå, 'tọ: sọ kọ'bilä, 'jå. Kọ'bilä sä 'vün 'mäčäjọ, 'nä, g'do sä 'sė:kå.

$J a$, to so kobile, ja. Kobile se ven mečejo, ne, ko se seka.

A: 'Jå, på d'vo: 'kujå, på d'vė:, d'vo: räz'ni:kå, 'nä. 'Rè:žä på 'tüdi, Trostä'jox:k jä 'nẹgdå 'rẹzọ, 'nejää 'mẹjọ 'kujọf, nå fä'runịkä.

Ja, pa dva konja pa dve, dva reznika, ne. Reže pa tudi, Trstenjak je nekdaj rezal, ni imel konjev, na ferunike.

D: 'Kå på jä 'tọ:?

Kaj pa je to?

A: 'Tọ: på sọ nå t'ri:, š'tirị 'ọ:kä pọ š'tirị - fä'runikä.

To pa so na tri, štiri očesa (oke) po štiri-ferunike.

D: 'Tọ: jä 'dukšị räz'ni:k, 'nä?

To je daljši reznik, ne?

A: Pọ t'rir, š'tirị 'ọ:kä. 'Kåkši jä 'tro:s 'bijọ. På tẹ pọ š'tirị, pọ 'šẹ:st jä 'tüdị 'mẹjọ, 'nä, 'kåk jä 'bijọ 'trąs. På 'nič 'kujọf, 'un jä 'tọ: 'nè: t'rẹbọ 'kujọf 'vẹ:zåtį.

Po tri, štiri očesa (oke). Kakršen je trs bil. Pa potem po štiri, po šest je tudi imel, ne, kakor je bil trs. Pa nič konjev, njemu ni bilo treba konjev vezati.

D: 'Kåk på sä jä 'tẹ: 'ovọ̣ 'rẹzålọ, 'kä jä bị'lọ: nå 'kol 'nẹgdå? G'lix 'tå:k, 'nä, nå 'tọtä fä'runikä.

Kako pa se je potem tisto rezalo, kar je bilo na kol nekdaj? Ravno tako, ne, na te ferunike.

A: G'lix 'tå:k, g'lix 'tå:k, 'jå.

Ravno tako, ravno tako, ja.

D: 'Tå:n sọ g'lix fä'runioä bị'lẹ̣:, 'nä?

Tam so ravno ferunike bile, ne?

A: 'Nẹ:, 'tån sọ g'lix 'tåk 'kuji bị'lii.

Ne, tam so ravno tako konji bili.

D: G'lix 'tå:k sọ 'kujị bị'liz? Ravno tako so konji bili?

A: G'lix 'tå:k jä 'bijọ t'ross, 'nä, på g'lix 'tåk ... Ravno tako je bil trs, ne, pa ravno tako ...

D: F'čó:sịik jä 'kẹrị 'mẹjọ šä s'coj 'kol, på ... Včasih je kateri imel še zraven kol, pa ...

A: F'såkši jä 'mẹjọ 'kol 'pọ:läk, på 'kujå s'coj z'vẹ:zånägå. 'Točnọ, 'zäj sän sä s'pọttịlå, 'goräx, kị jä 'Vẹlnår 'mẹjọ. 'Tọ: jä 'tọ:.

Vsakje imel kol poleg, pa konja zraven zvezanega. Točno, zdaj sem se spomnila, zgoraj, kjer je Velnar imel. To je to. 


\section{Deli vinograda}

B: 'Sig'do:r sä 'räčä 'säp, 'tọ: jä nå b'rè:gi, kär 'zäj bọn tị 'tọ: pọ'vẹdọ, 'nẹgdå sọ bị'lẹ:, 'tọ: jä v 'vẹrtikkålnịx gọ'ricåx. V 'vẹrtịkålnịx gọ'ricåx sọ 'moglä 'bitị g'råbịcä. Nå f'såkšix 'pẹdäsẹt 'mẹtrọf jä 'bijọ, 'kåk bị 'tọ: 'räkọ, 'vẹrtịkålnị, 'nè:jä, 'vẹrtịkålå jä v g'råbọ, 'tọ: sä p'rơ:vị, 'vodọ'råvnọ, 'vodọ'råvni ọd'vơd 'vodä ịn 'tọ: sä jä 'räklọ g'råbịcå. 'Tọ: jä bị'lọ: nå f'såkšịx 'pẹdäsẹt 'mẹtrọf. In 'tistọ jä bị'lọ: spä'lå:nọ ... åli 'tåk åli på 'tåk. Ålị på 'målọ 'tåk. (Z roko nakazano, da grabica lahko poteka pravokotno na vrste, lahko pa malo poševno, odvisno od nagiba terena.) 'Tistọ jä vg'lo:vnän bị'lọ: zå ịs'cẹjånjä 'vodä. Kär, 'tọ: jä 'zä:j, g'nä:s 'dè:n, 'näj'vẹ:kši prọb'lẹm, kå pọ f'soj dọ'žini på po kọlọ'miji 'vodå 'täčä 'dôn:l. In s'koplä 'tüdio dọ 'mẹtär g'lobọkọ. 'Nẹdå på sä jä 'tọ: 'rọ:čnọ 'dẹlålọ inn 'tọ: jä st'rogọ bị'lọ: g'råbịcä. 'Tẹ: på jä 'bijọ 'säp, 'gọ:rji 'dè:1, sä'pi:nå, på 'doläx åli på s'pọ:dji 'dè:l. 'Tåk sä jä 'tẹ:, nå t'ri: 'dè:lä sä jä pọ nå'vớ dị tọ: råz'dè:lịlọ.

Vedno se reče sep, to je na bregu, ker zdaj ti bom to povedal, nekdaj so bile, to je $v$ vertikalnih goricah. Vvertikalnih goricah so morale biti grabice. Na vsakih 50 metrov je bil, kako bi temu rekel, vertikalni, ni, vertikala je v grabo, to se pravi, vodoravno, vodoravni odvod vode in temu se je reklo grabica. To je bilo na vsakih 50 metrov. In tisto je bilo speljano ... ali tako ali pa tako. Ali pa malo tako. [..] Tisto je v glavnem bilo za izcejanje vode. Ker, to je zdaj, dandanes, največji problem, da po vsej dolžini pa po kolomiji voda teče dol. In skoplje tudi do meter globoko. Nekdaj pa se je to ročno delalo in to je strogo bilo grabice. Potem pa je bil sep, zgornji del, sepina, pa doli ali pa spodnji del. Tako se je potem, na tri dele se je po navadi to razdelilo.

\section{Klopotec}

M: 'Kọ:n g'rẹmọ 'zäj, dọ klọ'pọ:tcå? 'Nè: gå t'rẹbå 'dọ:l jä'måti̊. Kam gremo zdaj, do klopotca? Ni ga treba dol jemati.

B: 'Totị 'dè:l sọ 'vẹtrncä, g'rẹ: däl jä, nå g'rẹ: dlio sọ 'måcläki, 'tẹ: på jä 'däskå på 'mätlå. D'rü:gọ på 'nẹgå. På zå'vọ:rå. Ål på p'rẹmzå 'läxkọ 'räčämọ. 'Jå, 'nọ, s'tôxläc, 'tọ: jä 'totị 'dė:l, ki jä g'rẹ: däl 'goräx, 'nä?

Ta del so vetrnice, gredelj je, na gredlju so macljeki, potem pa je deska pa metla. Drugega pa ni. Pa zavora. Ali pa premza lahko rečemo. Ja, no, stolec, to je ta del, ki je gredelj gori, ne?

\section{Cuhta}

Č: 'Nè:? B'räs? 'Nẹ, 'tẹ: på mi jä 'Rusọf S'tånkọ på 'u:n 'tọ: råz'lågọ, kå sọ 'nẹgdå 'mẹlị 'tåkšnä p'räšä, kå sị 'nẹkåk, 'tåk kåk 'änọ 'kurpọ 'mẹjọ. 'Kurpọ, på 'notrị blå'gọ:, 'tåk kåk ọd 'änägå 'žåklå. In f'tisti 'žåkäl si d'jơ: 'tơtọ säm'lẹtọ g'rọ:zdjä, st'rẹtånọ, ọ'kọ:lio på 'tẹ: 'kurpọ, 'tẹ: på jä 'tistọ 'nẹkåk stịs'kơ:vålọ. Če sän jås p'råf 'råzmijọ.

Ne? Brez? Ne, potem pa mi je Rusov Stanko pa on razlagal, da so nekdaj imeli take preše, da si nekako, tako kot eno košaro imel. Košaro, pa notri blago, tako kot od kakega žaklja. In v tisti žakelj si dal to zmleto grozdje, stretano, okrog pa potem košaro, potem pa je tisto nekako stiskalo. Če sem jaz prav razumel. 
D: 'Čüjọ sän zå 'cü:xtọ ...

Slišal sem za cuhto ...

Č: In 'totọ blå'gọ:, kị sä jä 'no:pịlọ ...

In to blago, ki se je napilo ...

... sä jä 'no: pịlọ 'totägå 'sokå in g'do: si 'kåkšägå pi'jọ:ncå 'vidijọ, sị 'räkọ, 'toți på jä 'pijån kåk 'cü:xtå. Nä, 'tọ: jä bịi'lọ: s 'tè:n pộvẹ:zånọ.

... se je napilo tega soka in ko si kakega pijanca videl, si rekel, ta pa je pijan kot cuhta. Ne, to je bilo s tem povezano.

\section{$4 \quad$ Povzetek}

V prispevku so obravnavani narečni vinogradniški in kletarski izrazi, ki jih uporabljajo vinogradniki, doma v prleški vasi Cven, ki leži na zahodnem robu Panonske nižine. Govor vasi Cven spada v prleško narečje panonske narečne skupine. Naglašeni samoglasniki so dolgi ali kratki, nenaglašeni le kratki. Zastopniki psl. staroakutiranih dolgih in novoakutiranih kratkih samoglasnikov ter umično naglašenih $\partial, e, o$ so v govoru večinoma še kratki. Samoglasniški sistem je monoftongičen.

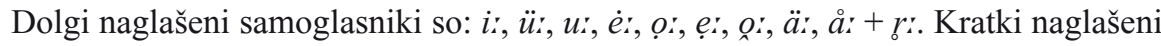

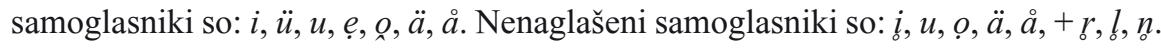
Soglasniški sistem se od sistema slovenskega knjižnega jezika zelo malo razlikuje, drugačna je le distribucija soglasnikov.

Cvenu najbližji vinogradi spadajo v vinorodno deželo Podravje, natančneje v ljutomersko-ormoški vinorodni okoliš. Ker sta vinogradništvo in vinarstvo zelo stari in razširjeni kmetijski panogi, je leksika zelo bogata. V članku je predstavljenih 115 slovarskih iztočnic. Veliko leksemov je podobnih knjižnim slovenskim (ključ, koš, metla, mlin, ročka, tolkač ...), precej je prevzetih iz nemščine (gutedel, pintar, šafla, šlah, štibla ...), nekateri so skupni s hrvaškim kajkavskim narečjem: šafla, štopelj (štopl), trahtar (trahter), vkapljati (fkaplati), ${ }_{11}^{11}$ brajda, izabela (ezibela), gorice, grozdje, klopotec, puta, šef, trs. ${ }^{12}$ Pri primerjavi leksike s SSKJ in Pleteršnikovim slovarjem se je našlo kar nekaj leksemov, ki jih v SSKJ ni, v Pleteršnikovem slovarju pa so zajeti: cuhta, davati, mojnga, olup, pavok, petljičje, pintar, pučel, remenec, vretenariti. Največ leksemov, ki jih ni ne v SSKJ ne v Pleteršnikovem slovarju ali se $\mathrm{v}$ nobenem od teh dveh ne pojavijo $\mathrm{v}$ istem pomenu, sem našla $\mathrm{v}$ slovarju Tomislava Lipljina Rječnik varaždinskoga kajkavskog govora (Lipljin 2002), in sicer šafla, štopelj (štopl), trahtar, vkapljati; v Bezlajevem etimološkem slovarju so predstavljeni leksemi lakovnica (lakomica), panoga, trahtar (trahter). Leksem lakovnica sem našla tudi v Novakovem Slovarju stare knjižne prekmurščine.

Besede brez označevalnika v slovarju so nezaznamovane. Nekateri leksemi so označeni s časovnimi označevalniki, in sicer kot zastarelo: cuhta, ferunika,

${ }^{11}$ Po primerjavi s slovarjem Tomislava Lipljina.

${ }^{12}$ Po primerjavi z neobjavljenim gradivom za slovar međimurskega dialekta Đura Blažeke. Gradivo je posneto v kraju Brezje (pri Čakovcu). Dr. Blažeki se za posredovano gradivo najlepše zahvaljujem. 
flokša, petljičje, rebljač, zrebljati; kot starinsko: bobika, četrtnjak, kobila, konj, panoga, pintar, poščip, prstek, stretani, štibla, tretač, tretati, vkapljati; kot redko: naštekati, sepina, tukla. $\mathrm{V}$ tem izboru iz celotnega slovarčka je le en terminološko zaznamovan leksem (kabrnik), ni pa zvrstno zaznamovanih.

Leksemi brajda, bratva, cuhta, čep, četrtnjak, dveri, grabica, igla, kamen, kobila, koš, preslice, preša, vaga ... se, sodeč po razpravah Mihaele Koletnik, uporabljajo tudi v drugih že raziskanih govorih prleškega narečja, nekateri pa njegove meje znatno presegajo.

\section{$5 \quad$ Literatura}

Baša 2002 = Helena Baša, Vinogradništvo in kletarsko izrazje Zalošč v srednji Vipavski dolini: diplomsko delo, mentorica izr. prof. dr. Vera Smole, Ljubljana: Filozofska fakulteta, 2002. (Tipkopis.)

Bezlaj 1-5 = France Bezlaj, Etimološki slovar slovenskega jezika I-V, avtorji gesel France Bezlaj - Marko Snoj - Metka Furlan, Ljubljana: Mladinska knjiga; SAZU - ZRC SAZU, 1976-2007.

Blažeka 2010 = Đuro Blažeka, Iz slovarja medžimurskega narečja, neobjavljeno gradivo, posredovano po elektronski pošti 14. 1. 2010.

Finka 1984-= Rječnik hrvatskoga kajkavskoga književnog jezika, ur. Božidar Finka - Radoslav Katičić (od 3. knjige), Zagreb: Jugoslavenska akademija znanosti i umjetnosti, 1984-.

Doberšek 1968 = Tit Doberšek, Vinogradništvo, Ljubljana: Državna založba Slovenije, 1968.

Hrček 1994 = Lojze Hrček, Kmetijski tehniški slovar 7: vinogradništvo = Zbornik Biotehniške fakultete Univerze v Ljubljani - agronomija, supl. 19 (1994).

Koletnik 1996 = Mihaela Koletnik, Vinogradniška terminologija na Gomili pri Kogu, v: Borkov zbornik, ur. Marko Jesenšek - Viktor Vrbnjak, Maribor: Slavistično društvo, 1996 (Piramida), 91-104.

Koletnik 2004 = Mihaela Koletnik, Miklošičevo vinogradniško besedje v Pleteršnikovem slovarju, v: Besedoslovje v delih Frana Miklošiča, ur. Zinka Zorko - Mihaela Koletnik, Maribor: Slavistično društvo, 2004 (Zora 31), 148-157.

Koletnik 2006a = Mihaela Koletnik, Izposojenke v prleškem vinogradniškem besedju, Annales: series historia et sociologia 16 (2006), št. 1, 179-188.

Koletnik 2006b = Vinogradniška terminologija na Ženiku in v Biserjanah, rojstnem kraju Antona Korošca, Časopis za zgodovino in narodopisje 77 (2006), št. 2-3, 243-254.

Koletnik $2007=$ Besedje $\mathrm{v}$ severovzhodnem narečnem prostoru, v: Besedoslovne spremembe slovenskega jezika skozi čas in prostor, ur. Marko Jesenšek, Maribor: Slavistično društvo, 2007 (Zora 49), 347-423.

Kosi 2007 = Mateja Kosi, Vinogradniško in kletarsko izrazje v prleški vasi Cven: diplomsko delo, mentorica red. prof. dr. Vera Smole, Ljubljana: Filozofska fakulteta, 2007. (Tipkopis.) 
Lipljin 2002 = Tomislav Lipljin, Rječnik varaždinskoga kajkavskog govora, Varaždin: Garestin, 2002.

Mukič 2005 = Francek Mukič, Porabsko-knjižnoslovensko-madžarski slovar, Szombathely: Zveza Slovencev na Madžarskem, 2005.

Novak 2006 = Vilko Novak, Slovar stare knjižne prekmurščine, Ljubljana: Založba ZRC - ZRC SAZU, 2006.

Pleteršnik 2006 = Maks Pleteršnik, Slovensko-nemški slovar, ur. Metka Furlan, Ljubljana: Založba ZRC - ZRC SAZU, 2006. (Transliterirana izdaja.)

SSKJ 1-5 = Slovar slovenskega knjižnegajezika 1-5. Ljubljana: SAZU -DZS, 19701991.

Safran 2004 = Nataša Safran, Vinogradniško besedje na Kapelskem Vrhu, diplomsko delo, mentorica doc. dr. Mihaela Koletnik, Maribor: Pedagoška fakulteta, 2004.

Skaza 1991 = Anton Skaza, Kletarjenje je užitek, Ljubljana: ČZP Kmečki glas, 1991.

Skočir 1990 = Ivan Skočir, Malo praktično vinogradništvo, Maribor: Založba Obzorja, 1990.

Skok 1-4 = Petar Skok, Etimologijski rječnik hrvatskoga ili srpskoga jezika 1-4, Zagreb: JAZU, 1971-1974.

Snoj 1997 = Marko Snoj, Slovenski etimološki slovar, Ljubljana: Mladinska knjiga, 1997.

Škofic 2004 = Jožica Škofic, Fonološki opis govora Juršincev v Slovenskih goricah (SLA 378), Jezikoslovni zapiski 10 (2004), št. 2, 103-119.

\section{Wine-growing and wine-cellar terminology in the village of Cven, Prlekija}

\section{Summary}

This article deals with wine-growing and wine-cellar dialect terminology used by winemakers in the village of Cven, Prlekija, on the western edge of the Pannonian Plain. The subdialect of the village of Cven belongs to the Prlekija dialect of the Pannonian dialect group. Stressed vowels can be long or short, and unstressed ones are short. The reflexes of PSl. old acute long and neoacute short vowels as well as $\partial, e, o$ with retracted stress are primarily still short. The vowel system is mono-

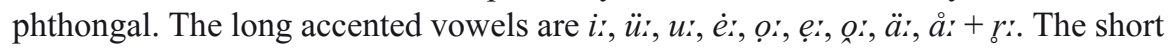
accented vowels are $i, \ddot{u}, u, e, o, \ddot{a}, \stackrel{a}{a}$. The unaccented vowels are $i, u, o, \ddot{a}, \stackrel{a}{a},+r$, $l, n$. The consonant inventory differs very little from standard Slovenian; only the distribution of consonants is different.

The vineyards closest to Cven are part of the Ljutiomer-Ormož winegrowing district within the Drava Valley winegrowing region. Because wine-growing and winemaking are very old and widespread agricultural activities, this lexical material is very rich. The article presents 115 dictionary headwords. Many of the lexemes are similar to standard Slovenian (ključ 'key', koš 'basket', metla 'broom', mlin 'mill', ročka '(watering) can', tolkač 'mallet', etc.), many are borrowed from German (gutedel 'Chasselas', pintar 'cooper', šafla 'shovel', šlah 'tube', štibla 'shoot', etc.), and some are shared with the Kajkavian dialect of Croatian. 